DOI: $\underline{\text { 10.20472/BM.2019.7.1.008 }}$

\title{
ARE INDIVIDUAL INNOVATORS INVISIBLE?
}

\author{
VIOLETA SUGAR, ALEN BELULLO, EMIN DZANIC
}

\section{Abstract:}

The research about the population of individual inventors/innovators in Croatia was carried out with the aim of finding answers to the following questions: 1. How many inventions/patents in Croatia are (not) commercialized; 2 . What are the reasons of (un)successful commercialization of Croatian individual inventors' inventions/patents; 3 . Is there any correlation between various forms of support for inventors / patent owners and successful commercialization; 4. Could education/training contribute to the successful commercialization of inventions/patents? The research was carried out on individual inventors/innovators in Croatia via combination of online questionnaire and telephone interviews. The acquired data were analyzed by descriptive statistics. Based on the results of the research, the literature and practical experience of the project "Innovation Management", which took place at the Faculty of economics and tourism "Dr. Mijo Mirkovic", a typology of Croatian individual inventors / innovators has been created.

\section{Keywords:}

innovation management; individual inventor/innovator; innovation eco system; education; support for commercialization

JEL Classification: 031

\section{Authors:}

VIOLETA SUGAR, Faculty of Economics and Tourism "Dr. Mijo Mirković", Juraj Dobrila University of Pula, Croatia, Croatia, Email: vsugar@unipu.hr

ALEN BELULLO, Faculty of Economics and Tourism "Dr. Mijo Mirković", Juraj Dobrila University of Pula, Croatia, Croatia, Email: abelul@unipu.hr

EMIN DZANIC, Medicopharmacia, Croatia, Email: emin.dzanic@gmail.com

\section{Citation:}

VIOLETA SUGAR , ALEN BELULLO, EMIN DZANIC (2019). Are Individual Innovators Invisible?. International Journal of Business and Management, Vol. VII(1), pp. 104-124., 10.20472/BM.2019.7.1.008 


\section{Introduction}

Innovations are one of the key topics of the EU Council (Innovation Union), as well as one of the crucial questions of Croatian strategic development. The Innovation Union is one of the seven flagship initiatives of the Europe 2020 strategy for smart, sustainable and inclusive growth, with the aim to do the following: "make Europe into a world-class science performer; remove obstacles to innovation (such as expensive patenting, market fragmentation, slow standard-setting and skills shortages, which currently prevent ideas getting quickly to market; and revolutionise the way public and private sectors work together, notably through Innovation Partnerships between the European institutions, national and regional authorities and business." 1 In 2008 The European Commission has created the European Institute of Innovation and Technology (EIT) to address the European Paradox where, despite excellence in research, highly skilled graduates and dynamic companies, the EU countries are still lagging behind competitors (the US and Japan in particular) in terms of business creation and bringing ideas to market (Dosi, Llerena, Sylos Labini, 2005; http://europa.eu/rapid/press-release SPEECH-13512 en.htm). Weitzmann (1998) provided description of the problem of reduced competitiveness and the phenomenon of the European paradox: "The final borders of growth have not largely limited our capacity to create new ideas, but our ability to transform the multitude of ideas into useful forms." However Dosi, Llerena and Sylos Labini (2006) argue that no overall 'European Paradox' with leading science but weak 'downstream' links can be observed; on the contrary, significant weaknesses reside at the two extremes, first, European system of scientific research lagging behind the US in several areas and, second, a relatively weak European industry; the latter characterized on average by a somewhat lower presence in sectors based on new technological paradigms (such as ICT and biotechnologies), by a lower propensity to innovate, and by a relatively weak participation in international oligopolies in many activities.

Economic sustainability is one of the most important priorities in Croatia, and National Competitiveness Council keep recommending a growth model based on productivity and exports $(2009,2010,2014)$. One of the key prerequisites for achieving productivity and exports is investment in innovation by investing in research and development (R\&D). Furthermore, innovation management and commercialization of inventions are crucial for return on investment and for ensuring the funds for further research, and creating products with higher added value, which positively affect the competitiveness of the economy. One of the most important indicators of the intensity of R\&D in a given country is the number of protected innovations (number of patents and products of industrial design) as final products resulting from such activities. Number of patents in a country is also directly related to GDP (Frame, 1991). The idea for an innovative product/service usually comes from an individual or a group of very creative people, who often do not have the resources, the patience or specific skills required for realization and commercialization of their inventions. Usually, there is a kind of a gap between the creativity and a successful product/service.

\footnotetext{
${ }^{1}$ http://ec.europa.eu/research/innovation-union/index en.cfm?pg=intro
} 
It is difficult to quantify the amount of innovation undertaken in an economy, so there is little available empirical evidence assessing the contribution made by innovation to growth (Crosby, 2000). Commercialization of inventions increases profitability and business competitiveness, as well as sustainability of the production (Veža, Prester, 2007). R\&D investment has significant impact on the number of registered patents and number of patents affects the GDP (Pozzi, 2010). Increases in patenting activity lead to increases in both labour productivity and economic growth (Crosby, 2000). At the beginning of the 20th century more than $80 \%$ of US patents were awarded to individual inventors (Pavitt, 1998 in Meyer, 2004). This situation has radically changed since industrial companies with their large-scale research laboratories dominate patenting these days, but nevertheless inventors still make a considerable contribution to overall patenting.

The foundation of all innovation are creative ideas, and it is individuals or groups who generate, promote, discuss, modify, and ultimately realize ideas; innovative activities of developing, promoting, discussing, modifying, and implementing ideas require a broad variety of substantial cognitive and socio-political efforts and investments (Janssen \& all. 2004). It is a long, multidisciplinary and complex way from the protected, patented idea to the innovation, as a product available for customer to allocate his money. Inventors are at the beginning of this chain, and should they achieve commercial success they need to be aware of all the elements of the entire process, to clearly perceive and evaluate their role and capabilities. They need various support and innovation management skills. Many inventors, patent owners are not entrepreneurs, nor members of research institutions or development departments of large companies. They usually lack the skills, knowledge and entrepreneurial features needed for successful commercialization of their inventions (Želinski-Matunec, 2002).

Central government support appears to be one of the most important determinants of R\&D. Receiving central government support increases by 2.3 percentage points the intensity of R\&D (Garcia, Mohnen, 2010). The rate of return on R\&D in terms of innovative sales is of the order of $110 \%$ ( 1 Euro of $R \& D$ yields a net 1.1 Euro increase in innovative sales). Busom (2000) found that in the aggregate subsidies increased R\&D expenditures in Spanish firms by $20 \%$, but that for $30 \%$ of the firms complete crowding out could not be excluded. González, Jaumandreu and Pazó (2005) point out a stimulating effect of R\&D subsidies in Spain both in the intensity and in the propensity of doing R\&D. Czarnitzki et al. (2004) and Bérubé and Mohnen (2009) established that respectively $R \& D$ tax incentives and $R \& D$ subsidies increased the proportion of innovators and especially world first innovators among Canadian firms. Few studies have quantified the effect of government support on the share of innovative sales. Czarnitzki and Licht (2006) state that public R\&D grants increased the share of sales due to new products by 4 percentage point in West German firms and 1.5 percentage points in East German firms. Public authorities expect that increasing R\&D investment causes intensified technological progress and finally accelerates growth in the long-run. In order to stimulate these private R\&D activities, governments usually offer a wide range of public incentives like R\&D subsidies, tax credits, technological consultancy etc. (Czarnitzki, Lopes Bento, 2012, 2014). 
In Croatia, there are a significant number of patents owned by non-institutional inventors who had invested their resources but did not consume their patent rights, to their own and to the detriment of potential partners, local communities and the state. Therefore, there is a need and opportunity for education related to all aspects of innovation management, starting from intellectual property rights, through the process of evaluation of individual innovation market value and finally improvement of communication and presentation skills. The economic, financial and social importance of innovation in Croatia has been recognized in the Strategy of fostering innovation 2014-2020 (http://www.mingo.hr/public/documents/Strategija poticanja inovacija 1812 14.pdf), but has not been realised much so far.

Table 1. Industrial property in the force in the Republic of Croatia (December 2016)

\begin{tabular}{|c|c|c|c|c|}
\hline & & Residents & $\begin{array}{l}\text { Non- } \\
\text { residents }\end{array}$ & Total \\
\hline \multirow{3}{*}{ Trademarks } & & 13.901 & 14.756 & 28.657 \\
\hline & \multicolumn{3}{|c|}{ Under the Madrid Agreement } & 93.282 \\
\hline & \multicolumn{3}{|c|}{ Total trademarks } & 121.939 \\
\hline \multirow{3}{*}{ Patents } & & 148 & 6.214 & 6.362 \\
\hline & $\begin{array}{l}\text { Consensual } \\
\text { patents }\end{array}$ & 327 & 39 & 366 \\
\hline & \multicolumn{3}{|c|}{ Total patents } & 6.728 \\
\hline \multirow{3}{*}{$\begin{array}{l}\text { Industrial } \\
\text { designs }\end{array}$} & & 1.249 & 336 & 1.585 \\
\hline & \multicolumn{3}{|c|}{ Under the Hague Agreement } & 3.228 \\
\hline & \multicolumn{3}{|c|}{ Total Industrial designs } & 4.813 \\
\hline \multicolumn{4}{|c|}{ TOTAL } & 133.480 \\
\hline
\end{tabular}

Source: State Intellectual Property Office, http://www.dziv.hr/hr/o-zavodu/statistika-ind-vlasnistval (11.12.2016.)

According to the Global Competitiveness Index (2016-2017) Croatia has been stuck in the transition from the stage 2 (Efficiency-driven) to the stage 3 (Innovation-driven). The next step towards the Innovation-driven economy should require improvement of innovation capacity, as well as the capacity to encourage creativity, interaction, and collaboration between individuals and institutions; and the aptitude of its companies to commercialize new products. By the end of 2009 in Croatia there were 2.285 patents in force (State Intellectual Property Office (SIPO), 2010). The same year there were 318 
patent applications, 207 by Croatian residents, and granted 646 new patents. In 2015, a total of 186 patent applications were filed with the SIPO, which is the lowest recorded annual number of applications via the national route and represents a decrease of $7 \%$ compared to the previous year. Out of that number, a total of 169 applications were filed by resident applicants, representing a minimum difference compared to the 2014, when there were 170 applications filed. It is expected that the perennial decreasing trend of applications by domestic applicants in national procedure, primarily as a consequence of negative economic trends during several years in the country, is stopped (SIPO, 2015). In December 2016 there were 6.728 patents in force (Table 1), which indicates that there is a significant number of individual non institutional inventors/innovators, as well as of the vitality of innovative capacity in Croatia. There are around 20 associations of inventors in Croatia, whose member's inventions are considerable potential for commercialization. The individual inventors, patent applicants and/or patent owners have already invested in $R \& D$ and industrial property protection process before entering the market. They need various support and education for efficient market placement.

\section{Individual Inventors and Commercialisation Challenges}

Some people are disproportionately more likely to come up with novel and useful ideas, and that - irrespective of their field of expertise, job title and occupational background these creative individuals tend to display a recurrent set of psychological characteristics and behaviours. Creativity alone, however, is not sufficient for innovation: innovation also requires the development, production, and implementation of an idea (Garcia, Calantone, 2002). This is why the number of "latent" innovators is far larger than the number of actual innovations, and why we all have at some point generated great ideas that we never bothered to implement. The key difference between creativity and innovation is execution: the capacity to turn an idea into a successful service, product or venture. Entrepreneurship is the process by which creative ideas become useful innovations. Given that entrepreneurship involves human activity - it depends on the decisions and behaviours of certain people - a logical approach for understanding the essence of innovation is to study the core characteristics of entrepreneurial people, that is, individuals who are a driving force of innovation, irrespective of whether they are selfemployed, business founders, or employees. Formal education or training are essential for noticing new opportunities or interpreting events as promising opportunities. Contrary to popular belief, most successful innovators are not dropout geniuses, but well-trained experts in their field.

Trade secret has established itself as an alternative to patent. In comparison to patent, trade secret can last much longer but also carries many risks. Those two options are in opposition in their levels of transparency. While trade secret requires data secrecy, a patent bases its protection upon the fact that all data is publicly available (Lobel, 2013). Patent also cannot become a trade secret while trade secret can become a patent patented not only by its owner (WIPO). In that respect, due to its transparency and availability, a patent represents significant data source in innovation research as is the case in this paper.

Research dealing explicitly with individual inventors is scarce. The economic impact of patents, studied in the extensive paper "Value of European Patents" by Gambardella 
(2005) revealed that $55 \%$ of patents are commercialized by the applicant himself, $13 \%$ are licenced, while $36 \%$ are not economically used. It is worthwhile noting that only $5.13 \%$ of patents are used in starting new companies. Gambardella (2005) estimated values of patents and determined their distribution within Europe. He carried out a survey, where the minimum price was set by the innovator at the moment of reception of own patent rights. Regardless of the questionable methodology, the survey showed that only a portion of patents (16.81\%) is worth more than 3 million Euros, while $7.23 \%$ is worth more than 10 million Euros.

Without inovation there is no succesful product or service, but not all patents are guaranteed commercial success. The survey, measuring the success rate of innovators in Canada (Astebro, 2003), carried out via questionnaire on 1091 innovators, showed that $93 \%$ of patented inventions do not reach the market. $40 \%$ of those who do yield a positive outcome using internal rate of profitability finally resulted in $2.8 \%$ success. However, a question could be asked: why inventors venture into protection of their ideas? Another research analysed the motives of intellectual protection within the European Patent Office (EPO), carried out on 641 participants comparing the motives of individual inventor/innovator, small business owners and academic inventors/innovators (Veer \& Jell, 2012). The results revealed that academic inventors/innovators tend to licence their patents, while businesses and individual inventors/innovators use their patents as a signal to potential investors. It is interesting to note that individual inventors/innovators, compared to other groups, have a stronger motivation for preventing others to copy their protected idea whilst not venturing into production themselves.

It can be concluded that the golden age of "celebrity" innovators from the beginning of the last century is long gone. Bessen research (2004) tried to measure and compare popularity of individual inventors/innovators taking into consideration their appearance in The New York Times during their lifetime (in the period 1881 to 2001). The research showed that the old inventors/innovators (such as Edison, Wright and Bell) had much higher prevalence in magazines than their modern counterparts (Wozniak - cofounder of Apple, Clay - supercomputer, Bloomberg - Hepatitis B virus). The explanation for lower intensity of magazine prevalence/popularity of modern inventors/innovators the author finds in collaborative nature of modern complex invention/innovation process and shared success among various inventors/innovators, so they are not properly recognized.

According to Fleming and Singh (2008) individual inventors/innovators, in comparison to those working in collaboration, are creating more innovations of less importance and less innovations of higher importance. The advantage of cooperative model within the process of creating an innovation has already been stated, but what value and advantage do innovation and individual innovator model have? Lettl, Rost and vonWartburg (2009) analyzed the difference between corporative and individual inventors/innovators. The corporative milieu has the advantage in creating inventions/innovations of higher importance when problem solving demands diversity i.e. expertise in different fields. Diversity of individual inventors/innovators in the process of creating inovations presents a problem and the results could be of lesser quality compared to those of the corporate inventors/innovators. The advantage of individual inventors/innovators is apparent in cases of specialisation, when diversity to create invention/innovation is low, and the level of specialisation is high. Individual inventors/innovators can achieve the same or even 
higher rate of success in the context of innovation impact, then their corporative colleagues.

\section{Research Methodology and Results}

It is difficult to establish the number of individual inventors in Croatia. Due to the lack of a data base of individual inventors, the authors combined several sources: 1) the SIPO data base of patent applications; 2) the information about members of associations of inventors in Croatia; 3) the Genius Croatia, a platform for promotion, presentation and commercialization of Croatian innovative projects. The data from the associations varied, only few of them had quite useful web pages with information about their membership. The Genius platform only started gathering data, so their information also was scarce. According to the SIPO data base in January 2015 there were 3246 individuals with a variety of 19 possible phases of the patent application process. Majority had just one application, only few of them had more than 10 patent applications/granted. The SIPO does not track what happens with each application after it is granted with patent. In order to be able to use the SIPO data base, the authors had to sign the confidentiality agreement, stating that no information regarding individual inventors will be revealed, even though that there was no contact information (phone, e-mail), but the addresses, which, as it appears, were not always accurate. Consequently, the authors had to be creative in finding the way to communicate individual, non-institutional inventors. The research has been carried out via online survey, followed by the telephone interview. The convenience sample was formed and online survey sent via e-mail to the available addresses, but with the poor response rate. The telephone interviewing finally resulted with 143 valid questionnaires.

For the research the original questionnaire was designed by the authors aiming to confirm or reject the following hypothesis: $\mathrm{H} 1$ : There are a significant number of inventions/patents in Croatia that are not commercialized. H2: There is no difference between various forms of support for inventors and commercialisation of their inventions. H3: Education could help individual inventors in managing their inventions. 
Figure 1. The working status of respondents

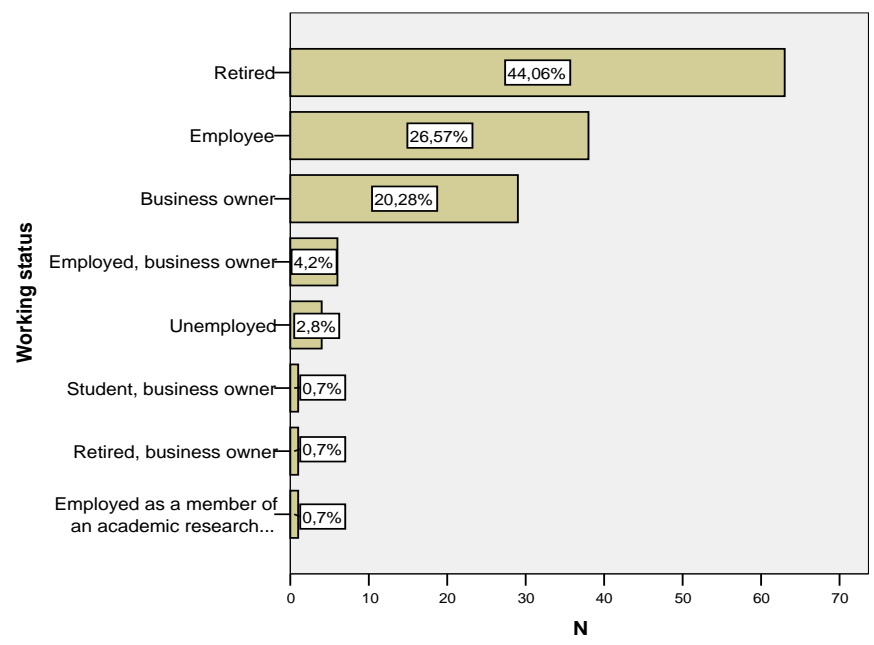

Figure 2: The educational level of respondents

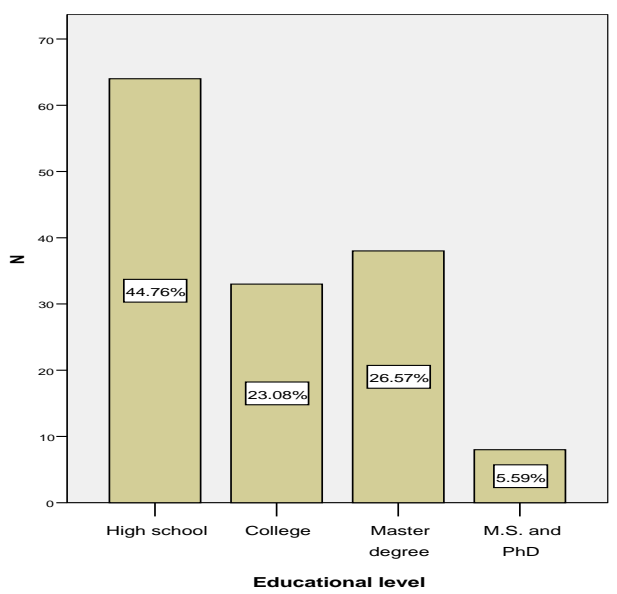

The answers to the question about the working status and education level revealed that majority (44,06\%) of the respondents were retired (Figure 1) and graduated from the high school (Figure 2). Regarding the support, the majority did not receive any for their invention/patent (Figure 3). As their major problems/needs as inventors, the respondents indicated entering the market and lack of financial support (Figure 4). They also indicated the following: lack of education and institutional support (the government institutions in Croatia do not recognize individual inventors), lack of cooperation with the SIPO, expensive patenting. 
Figure 3: Kind of support received

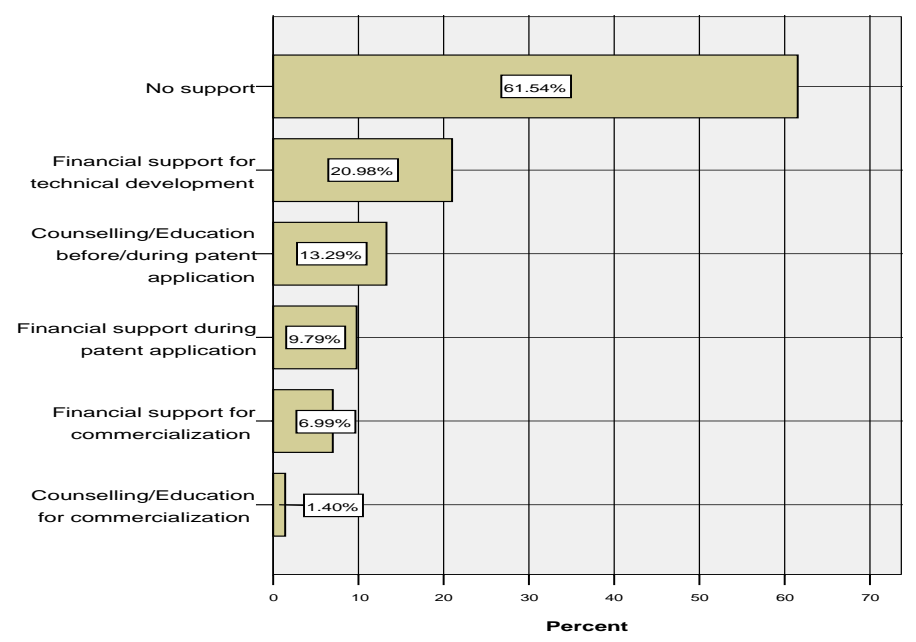

Figure 4: Major problems (needs) of inventors

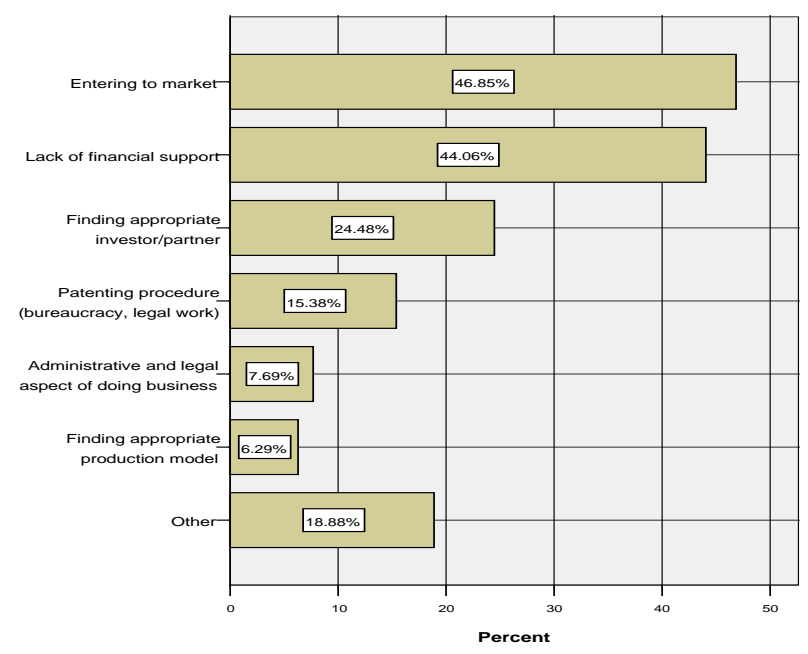

We asked about commercialisation practice: how did you commercialize your patent/invention (Figure 5); why did you not commercialize your invention(s) (Figure 6)? Majority owns a business which is selling their invention(s), some started a new business (start-up) or sold their intellectual property (patents). Under the option "other" the respondents answered the following: going to commercialize via the company where I am employed; looking for a partner; a member of my family is going to start up a business. The majority of problems (obstacles) in the process of commercialization are: finding a suitable partner/investor and lack of crucial knowledge and skills (Figure 6). 
Figure 5: Commercialisation practice

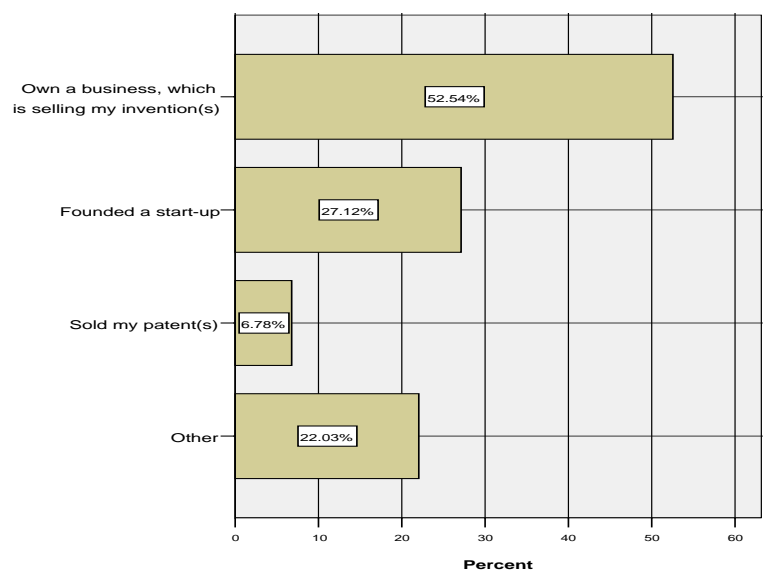

Figure 6: Commercialisation problems

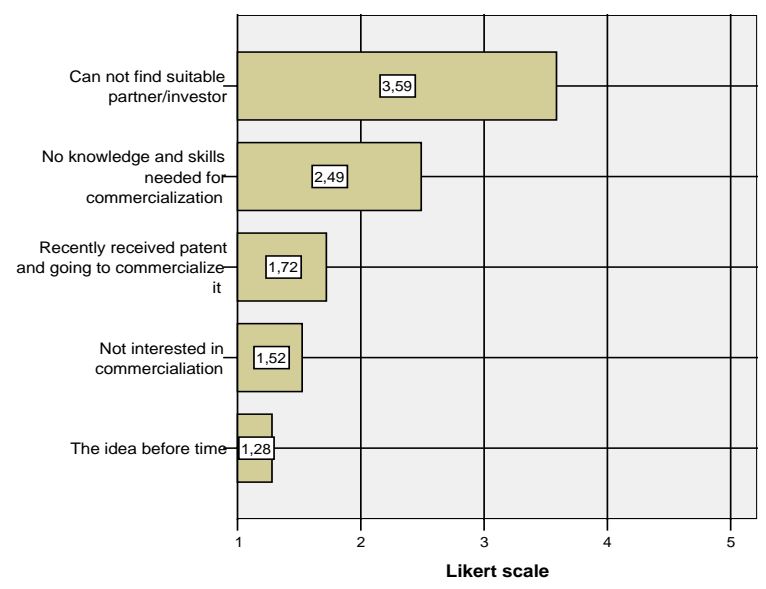

Figure 7: Intentions with the inventions

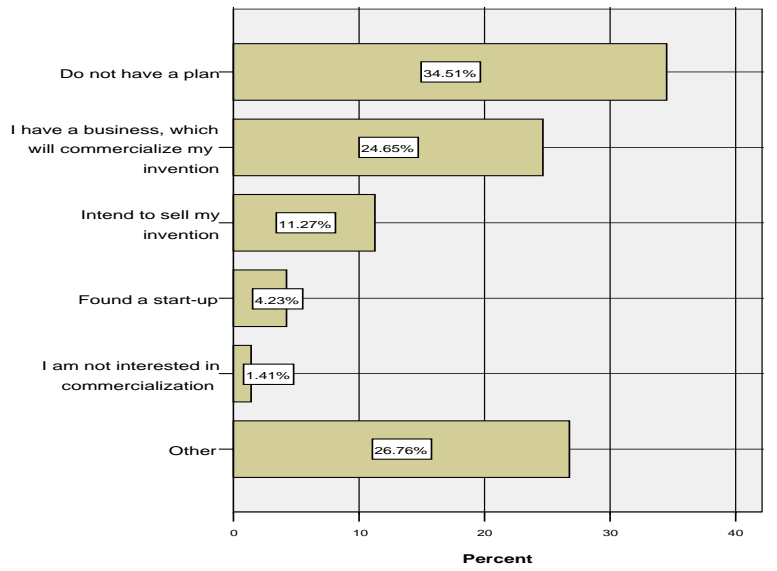

Interesting answers were received to the question about their intentions, what are their plans regarding their inventions (Figure 7). The majority did not have any plan at all. Furthermore, under the option "other" the respondents indicated once more that Croatia lacks support for individual inventors and that they are planning to sell their inventions, 
and look for a partnership abroad. Some also stated that the market should be educated about their inventions, as well as that they need some specific knowledge and skills in order to be capable for managing their own inventions.

\section{Typology and Education}

Innovators are not born at the frontier of knowledge; rather, they must initially undertake significant education. Furthermore, the frontier of knowledge varies across fields and over time (Jones, 2009). Starting up a business is a challenging endeavour requiring different sets of skills at different times. The inventor must have the ability to turn him or herself into an entrepreneurial personality and assemble a solid management if the start-up is to become a success (Nesheim, 2003 in Meyer, 2004). In the process of managing their own inventions/innovations inventors/innovators need education in order to increase the capacity and probability of successful products. The innovator becomes aware of the process of commercialization, of the information needed for the market assessment of the value of their inventions, as well as of the presentation skills needed for communication with potential partners and investors. The project "Innovation Management", which took place at the Faculty of Economics and Tourism (Juraj Dobrila University) in Pula in 2012, resulted with various insights regarding the typology of inventors/innovators, as well as of their needs in the process of commercialisation of their inventions. The aim of the project was to set up the educational module designed to help reducing the gap between inventors/innovators and investors. During the pilot phase activities 68 hours of educational workshops have been carried out and finally 10 participants presented their business cases to the expert committee. The specific objectives of the educational module were as follows: 1 ) to create and continually improve the annual cycle of lectures; 2) to achieve and maintain cooperation with various stakeholders, among which representatives of entrepreneurs, bankers, business angels and other potential investors; 3) to achieve and maintain cooperation with representatives of the target group, inventors' associations and their members inventors/innovators interested in education; 4) to enable students for learning-by-doing (the interdisciplinary teams of students were, as part of their obligatory courses Entrepreneurship and Economy and Strategic Accounting, developing business plans for the specific cases of the trainees/inventors). After the first year of implementation, the following results were achieved: a) a designed and harmonized curriculum; b) a team of quality lecturers assembled; c) educated group of 15 participants/inventors/innovators; d) a fund of 10 business cases presented before a committee composed of bankers, entrepreneurs, business angels and other potential investors. The overall results indicate that innovation and commercialisation capability could be improved by education. Some of the trainees were asked to meet the business angels, interested in their inventions, implicating the possibility of investment, funding their inventions. But the invited trainees did not respond. Why? The answer may be derived out of the typology both of the inventors-trainees (Table 2) and the survey respondents (Figure 8). The inventors-trainees were not yet ready to become entrepreneurs, they were creative inventors, but not willing to take a risk and a step out of their comfort zone. As for the survey respondents, majority of them were retired, therefore at the end of their active working life, obviously as well not willing to become entrepreneurs. 
Invention can become innovation with the help of entrepreneurship. Creativity of inventive people, as it was evident with the Innovation Management trainees, does not guarantee the success in innovation, meaning commercialisation. A variety of personal characteristics of inventors (and not all of them are keen on entrepreneurship), revealed a gap between invention and successful innovation. Similar profiles have been found among the trainees and the survey respondents (Figure 8, Table 2). Among the "other" there are combination of the types, such as entrepreneur and retired or entrepreneur and proprietor.

\section{Table 2. Typology of inventors detected in the Innovation Management project}

\begin{tabular}{|c|c|c|}
\hline Types of inventors & $\begin{array}{c}\text { Personal features of the } \\
\text { "Innovation Management" } \\
\text { trainees }\end{array}$ & $\begin{array}{l}\text { Personal features of the } \\
\text { survey respondents }\end{array}$ \\
\hline Entrepreneur & $\begin{array}{l}\text { I intend to start up a business } \\
\text { for selling my invention }\end{array}$ & $\begin{array}{l}\text { I have a company / I will } \\
\text { start up a business for } \\
\text { selling my invention(s) }\end{array}$ \\
\hline Proprietor & $\begin{array}{l}\text { I have a start-up / small } \\
\text { business }\end{array}$ & $\begin{array}{l}\text { My company (companies) } \\
\text { will sell my invention(s) }\end{array}$ \\
\hline $\begin{array}{l}\text { Avantime (invention } \\
\text { too novel) }\end{array}$ & $\begin{array}{l}\text { No one understands my } \\
\text { invention }\end{array}$ & $\begin{array}{l}\text { The idea (invention) is } \\
\text { premature; I have to educate } \\
\text { the market }\end{array}$ \\
\hline $\begin{array}{l}\text { Licencing / patent } \\
\text { transfer / employee }\end{array}$ & $\begin{array}{l}\text { Creative, not interested in } \\
\text { entrepreneurship, looking for } \\
\text { a partner / investor / } \\
\text { entrepreneur. } \\
\text { I will keep my day job and } \\
\text { work on my invention in my } \\
\text { free time. }\end{array}$ & $\begin{array}{l}\text { Intend to sell the invention to } \\
\text { the third party. } \\
\text { I will offer cooperation to my } \\
\text { employer. }\end{array}$ \\
\hline Academic & l & $\begin{array}{l}\text { Engaged at the academic } \\
\text { research project }\end{array}$ \\
\hline
\end{tabular}

Source: authors and Meyer (2004)

Regarding education/consultation and research before and after patent application (how often do you browse internet in research for similar solutions/products/services before patent application; how often do you consult with entrepreneurs and/or experts in the same industry/field of your invention, before/after the patent application), the 
Entrepreneur type, as expected, are more interested, based on 5-points Likert scales (Table 3), in browsing internet and consultation before patent application, as well as they tend to seek consultation after patent application, since they are interested in commercialization.

Figure 8: Typology of survey respondents

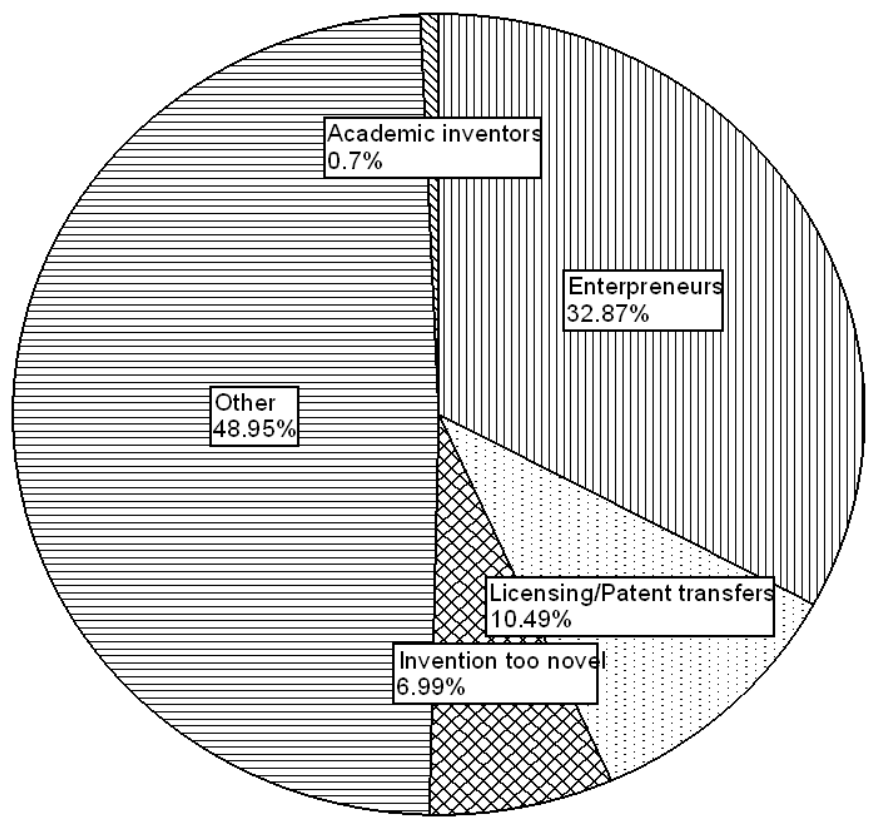

The difference of means of Likert scales among different groups of inventor types are tested by one-way analysis of variance (ANOVA). F-test statistics with levels of significance in parentheses are showed in the Table 3. According to them there are statistically significant differences $(p<0.05)$ among inventor types regarding all three categories: Browsing internet before patent application, Consulting before patent application, and Consultation after patent application. In all three cases the mean of the Likert scale of Entrepreneurs is statistically higher compared to the other inventor types.

Table 3: Education/consultation regarding patent application

\begin{tabular}{|c|l|l|c|c|c|}
\hline Inventor types & $n$ & $\begin{array}{c}\text { Browsing } \\
\text { internet } \\
\text { before patent } \\
\text { application }\end{array}$ & $\begin{array}{c}\text { Consultation } \\
\text { before patent } \\
\text { application }\end{array}$ & $\begin{array}{c}\text { Consultation } \\
\text { after patent } \\
\text { application }\end{array}$ \\
\hline Entrepreneurs & 47 & 3.98 & 3.68 & 3.62 \\
\hline Licensing/Patent & 15 & & 3.07 & 1.87 & 2.33 \\
\hline
\end{tabular}




\begin{tabular}{|c|c|c|c|c|}
\hline transfers & & & & \\
\hline Invention too novel & 10 & 2.30 & 2.30 & 2.50 \\
\hline Other & 71 & 3.62 & 3.06 & 3.31 \\
\hline$F$-value & & 3.507 & 6.159 & 3.380 \\
\hline$(p)$ & & $(0.017)$ & $(0.001)$ & $(0.020)$ \\
\hline
\end{tabular}

Bold: significant at the $5 \%$ level

Table 4: Commercialisation by inventor types

\begin{tabular}{|l|c|c|c|}
\hline \multicolumn{1}{|c|}{ Inventor types } & $n$ & Number of patents & $\begin{array}{c}\text { Commercialization } \\
\text { of patents }\end{array}$ \\
\hline Entrepreneurs & 47 & 2.28 & $87.23 \%$ \\
\hline Licensing/Patent transfers & 15 & 2.53 & $26.67 \%$ \\
\hline Invention too novel & 10 & 1.70 & $30.00 \%$ \\
\hline Other & 71 & 1.83 & $14.08 \%$ \\
\hline F-value & & 0.324 & $\mathbf{3 8 . 3 6 7}$ \\
$(p)$ & & $(0.808)$ & $\mathbf{( 0 . 0 0 0 )}$ \\
\hline
\end{tabular}

Bold: significant at the $5 \%$ level

Regarding the number of patents, there is no statistically significant difference among inventor types (Table 4; $F=0.324, p=0.808>0.05$ ), but there is statistically significant difference $(F=38.367, p<0.05)$ for commercialization of patents, in the sense that entrepreneurs commercialize patents significantly more $(87,23 \%$ of them) compared to the other groups of inventor types. 
Table 5: Contingency tables for commercialization of patents vs different forms of support

\begin{tabular}{|c|c|c|c|c|}
\hline \multirow{2}{*}{\multicolumn{2}{|c|}{ Forms of support }} & \multicolumn{2}{|c|}{$\begin{array}{c}\text { Commercialization of } \\
\text { patents }\end{array}$} & \multirow{2}{*}{$\begin{array}{l}\chi^{2} \\
(p)\end{array}$} \\
\hline & & No & Yes & \\
\hline \multirow{2}{*}{$\begin{array}{l}\text { Financial support for } \\
\text { technical development }\end{array}$} & No & $63.7 \%$ & $36.3 \%$ & \multirow{2}{*}{$\begin{array}{l}2.208^{*} \\
(.098)\end{array}$} \\
\hline & $\begin{array}{l}\text { Ye } \\
\mathrm{s}\end{array}$ & $46.7 \%$ & $53.3 \%$ & \\
\hline \multirow{2}{*}{$\begin{array}{l}\text { Counselling/Education } \\
\text { before/during patent } \\
\text { application }\end{array}$} & No & $64.5 \%$ & $35.5 \%$ & \multirow{2}{*}{$\begin{array}{l}6.145 \\
(.010)\end{array}$} \\
\hline & $\begin{array}{l}\text { Ye } \\
\mathrm{s}\end{array}$ & $31.6 \%$ & $68.4 \%$ & \\
\hline \multirow{2}{*}{$\begin{array}{l}\text { Financial support during } \\
\text { patent application }\end{array}$} & No & $63.6 \%$ & $36.4 \%$ & \multirow{2}{*}{$\begin{array}{l}5.075 \\
(.019)\end{array}$} \\
\hline & $\begin{array}{l}\text { Ye } \\
\mathrm{s}\end{array}$ & $28.6 \%$ & $71.4 \%$ & \\
\hline \multirow{2}{*}{$\begin{array}{l}\text { Counselling/Education for } \\
\text { commercialization }\end{array}$} & No & $61.0 \%$ & $39.0 \%$ & \multirow{2}{*}{$\begin{array}{l}1.045 \\
(.167)\end{array}$} \\
\hline & $\begin{array}{l}\text { Ye } \\
s\end{array}$ & $0 \%$ & $100.0 \%$ & \\
\hline \multirow{2}{*}{$\begin{array}{l}\text { Financial support for } \\
\text { commercialization }\end{array}$} & No & $63.2 \%$ & $36.8 \%$ & \multirow{2}{*}{$\begin{array}{l}5.538 \\
(.015)\end{array}$} \\
\hline & $\begin{array}{l}\text { Ye } \\
\mathrm{s}\end{array}$ & $20.0 \%$ & $80.0 \%$ & \\
\hline \multirow[t]{2}{*}{ No support } & No & $41.8 \%$ & $58.2 \%$ & \multirow{2}{*}{$\begin{array}{l}11.304 \\
(.000)\end{array}$} \\
\hline & $\begin{array}{l}\text { Ye } \\
\mathrm{s}\end{array}$ & $71.6 \%$ & $28.4 \%$ & \\
\hline
\end{tabular}

Bold: significant at the $5 \%$ level

${ }^{*}$ Significant at the $10 \%$ level

There is a significant number of inventions/patents in Croatia that are not commercialized $(\mathrm{H} 1)$. In our sample only $39.86 \%$ of inventors commercialized their inventions. If we narrow a sample and analyse only inventors with patents, the result is $42.24 \%$ of commercialized inventions. Based on the $z$-test for proportion, the difference between 
these two groups is not statistically significant $(z=-0.387, \operatorname{sign}=0.6985>0.05)$. If we perform a proportion test $\mathrm{H}_{0}: p=0.5$ vs $\mathrm{H}_{\mathrm{A}}: \mathrm{p}<0.5$; for the first group, we have $z=-2.42$ $(s i g n=0.0077<0.05)$ and for the group without inventors with no patent we have $z=-1.67$ $(\operatorname{sign}=0.047<0.05)$. In both situations, with 95 percent confidence, we can reject the null hypothesis that $50 \%$ of inventors commercialized their inventions in favour of one-sided alternative hypothesis that less than $50 \%$ of inventors commercialized their inventions.

Table 6. Types of problems of individual innovators and education

\begin{tabular}{|c|c|c|c|c|c|}
\hline \multirow{2}{*}{\multicolumn{2}{|c|}{ Type of problem/needs }} & \multicolumn{2}{|c|}{$\begin{array}{l}\text { Education could } \\
\text { help in } \\
\text { commercialization }\end{array}$} & \multicolumn{2}{|c|}{$\begin{array}{l}\text { Education should be } \\
\text { involved in the overall } \\
\text { system of support for } \\
\text { commercialization }\end{array}$} \\
\hline & & mean & $F(p)$ & mean & $F(p)$ \\
\hline \multirow{2}{*}{$\begin{array}{c}\text { Patenting procedure } \\
\text { (bureaucracy, legal } \\
\text { work) }\end{array}$} & No & 3.87 & \multirow{2}{*}{$\begin{array}{l}.436 \\
(.510)\end{array}$} & 4.65 & \multirow{2}{*}{$\begin{array}{l}1.162 \\
(.283)\end{array}$} \\
\hline & Yes & 4.09 & & 4.45 & \\
\hline \multirow{2}{*}{$\begin{array}{l}\text { Finding appropriate } \\
\text { production model }\end{array}$} & No & 3.89 & \multirow{2}{*}{$\begin{array}{l}.197 \\
(.658)\end{array}$} & 4.61 & \multirow{2}{*}{$\begin{array}{c}.366 \\
(.546)\end{array}$} \\
\hline & Yes & 4.11 & & 4.78 & \\
\hline \multirow{2}{*}{$\begin{array}{l}\text { Finding appropriate } \\
\text { investor/partner }\end{array}$} & No & 3.98 & \multirow{2}{*}{$\begin{array}{l}1.316 \\
(.253)\end{array}$} & 4.64 & \multirow{2}{*}{$\begin{array}{l}.190 \\
(.664)\end{array}$} \\
\hline & Yes & 3.66 & & 4.57 & \\
\hline \multirow{2}{*}{$\begin{array}{l}\text { Lack of financial } \\
\text { support }\end{array}$} & No & 3.89 & \multirow{2}{*}{$\begin{array}{l}.018 \\
(.893)\end{array}$} & 4.60 & \multirow{2}{*}{$\begin{array}{l}.143 \\
(.706)\end{array}$} \\
\hline & Yes & 3.92 & & 4.65 & \\
\hline \multirow{2}{*}{$\begin{array}{l}\text { Administrative and } \\
\text { legal aspect of doing } \\
\text { business }\end{array}$} & No & 3.91 & \multirow{2}{*}{$\begin{array}{l}.039 \\
(.843)\end{array}$} & 4.65 & \multirow{2}{*}{$\begin{array}{l}2.330 \\
.129\end{array}$} \\
\hline & Yes & 3.82 & & 4.27 & \\
\hline \multirow{2}{*}{ Entering to market } & No & 3.61 & \multirow{2}{*}{$\begin{array}{l}7.038 \\
(.009)\end{array}$} & 4.47 & \multirow{2}{*}{$\begin{array}{l}5.879 \\
(.017)\end{array}$} \\
\hline & Yes & 4.24 & & 4.79 & \\
\hline \multirow{2}{*}{ Other } & No & 3.90 & \multirow{2}{*}{$\begin{array}{l}.009 \\
(.925)\end{array}$} & 4.60 & \multirow{2}{*}{$\begin{array}{c}.347 \\
(.557)\end{array}$} \\
\hline & Yes & 3.93 & & 4.70 & \\
\hline
\end{tabular}


Bold: significant at the $5 \%$ level

There is no difference between various forms of support for inventors and commercialisation of their inventions $\left(\mathrm{H}_{2}\right)$. Based on the contingency table we performed the Chi-Square test with Fisher's correction for a $2 \times 2$ table. The results, $\mathfrak{R}^{2}$ statistics with levels of significance in parenthesis are showed in the Table 5 . These tests confirmed that there are statistically significant differences $(p<0.05)$ among successful commercialization of patents and counselling/education before/during patent application, financial support during patent application, financial support for commercialization. As the contingency tables in the Table 5 display, $68.4 \%$ of innovators who undertook counselling and/or education before, or during their patent application, succeeded in commercialization. Those who received financial support during patent application were more successful in commercialization (71.4\%), as well as those who received financial support for commercialization (80.0\%). Although the difference for counselling/education for commercialization is quite large (39\% vs $100 \%)$, we cannot reject the null hypothesis that the percentages are equal due to a very small number of observations.

Education could help individual inventors in managing their inventions $(\mathrm{H} 3)$. The overall mean of the Likert scale for the statement "Education could help in commercialization is 3.90, and for the statement "Education should be involved in the overall system of support for commercialization" is 4.62. Based on the $t$-test for paired samples $(t=-7.036$, $p=0.000<0.05$ ) we can conclude that there is a statistically significant difference between these two means. We can also conclude, based on the one-sample $t$-test of $\mathrm{H}_{0}: \mu=3$ vs $\mathrm{H}_{\mathrm{A}}: \mu>3$ for statements "Education could help in commercialization" $(t=7.41, p<0.05)$ and "Education should be involved in the overall system of support for commercialization" $(t=24.42, p<0.05)$, that inventors have a statistically significant positive belief regarding these issues.

The Table 6 shows Likert scale's means and corresponding F-value statistics with level of significance $(p)$ in parenthesis_for testing difference of means between two independent groups (individuals that have and do not have specific) problem. There is a statistically significant difference in means between groups only for problem Entering to market in sense that individuals that have problem with entering to market significantly $(p<0.05)$ think that education is more important for commercialization (mean=4.24 vs 3.61) as that education should be involved in the overall system of support for commercialization (mean $=4.79$ vs 4.47 ) compared to individuals that do not have problem with this issue. 
Table 7: Inventor types and education

\begin{tabular}{|l|c|c|c|}
\hline \multicolumn{1}{|c|}{ Inventor types } & $n$ & $\begin{array}{c}\text { Education could } \\
\text { help in } \\
\text { commercialization }\end{array}$ & $\begin{array}{c}\text { Education should be } \\
\text { involved in the overall } \\
\text { system of support for } \\
\text { commercialization }\end{array}$ \\
\hline Entrepreneurs & 47 & 4.00 & 4.55 \\
\hline $\begin{array}{l}\text { Licensing/Patent } \\
\text { transfers }\end{array}$ & 15 & 3.93 & 4.47 \\
\hline Invention too novel & 10 & 3.40 & 4.80 \\
\hline Other & 71 & 3.90 & 4.68 \\
\hline $\begin{array}{l}\text { F-value } \\
(p)\end{array}$ & & 0.465 & 0.580 \\
& $(0.707)$ & $(0.629)$ \\
\hline
\end{tabular}

There are minor differences between each of the types of inventors (Table 7) regarding the statement that education could help to commercialize their inventions and should be involved in overall system of support for commercialization, but the differences are not statistically significant $(p>0.05)$. As expected, entrepreneurs are more convinced that education could help in commercialization, than the other types.

\section{Conclusion}

The bases of innovation are creative ideas, and individuals or groups who generate, promote, discuss, modify, and ultimately realize them. Innovative activities of developing, promoting, discussing, modifying, and implementing ideas require a broad variety of substantial cognitive and socio-political efforts and investments. It is a long, multidisciplinary and complex way from the protected, patented idea to the innovation, as a product available for customer to allocate his money. Inventors are at the beginning of this chain, and should they achieve commercial success they need to be aware of all the elements of the entire process, to clearly perceive and evaluate their role and capabilities. They need various support and innovation management skills. Many inventors, patent owners are not entrepreneurs, nor members of research institutions or development departments of large companies. They usually lack the skills, knowledge and entrepreneurial features needed for successful commercialization of their inventions. The advantage of individual inventors/innovators is apparent in cases of specialisation, when diversity to create invention/innovation is low, and the level of specialisation is high. Individual inventors/innovators can achieve the same or even higher rate of success in the context of innovation impact, then their corporative colleagues. 
In Croatia there are a significant number of patents owned by non-institutional inventors who had invested their resources but did not consume their patent rights, to their own and to the detriment of potential partners, local communities and the state. Therefore, there is a need and opportunity for education related to all aspects of innovation management, starting from intellectual property rights, through the process of evaluation of individual innovation market value and finally improvement of communication and presentation skills. The economic, financial and social importance of innovation in Croatia has been recognized in the Strategy of fostering innovation 2014-2020, but has not been realised much so far. To start with there is no data base about individual inventors.

There are a significant number of inventions/patents in Croatia that are not commercialized. In our sample only $39.86 \%$ of respondents commercialized their inventions. Asked about the problems (obstacles) in the process of commercialization the majority of respondents identified finding a suitable partner/investor and lack of crucial knowledge and skills. Regarding their intentions, their plans with their inventions, the majority replied that they did not have any plan at all. Furthermore, they indicated that Croatia lacks support for individual inventors, as well as that they need some specific knowledge and skills in order to be capable for managing their own inventions. There is a consensus that education could help individual inventors in managing their inventions and entering the market. Moreover, they believe that education should be involved in the overall system of support for commercialization.

\section{References}

Bérubé, C. and P. Mohnen (2009), "Are firms that received R\&D subsidies more innovative?", Canadian Journal of Economics, 42(1), 206-225. https://doi.org/10.1111/j.1540-5982.2008.01505.x

Bessen, J. Great Inventors. (2004). http://www.researchoninnovation.org/Greatlnventors.pdf (accessed 1. 3. 2017).

Busom, I. (2000), "An Empirical Evaluation of the Effects of R\&D Subsidies", Economics of Innovation and New Technology, 9, 111-148. https://doi.org/10.1080/10438590000000006

Christopher, L., Rost, K., von Wartburg, I. (2009). "Why are some independent inventors 'heroes' and others 'hobbyists'?" Research Policy, Vol. 38, pp. 243-254. https://doi.org/10.1016/j.respol.2008.12.004

Czarnitzki, D., P. Hanel and J. Rosa (2004), "Evaluating the impact of R\&D tax credits on innovation: A microeconometric study on Canadian firms", ZEW discussion paper 04-77. https://doi.org/10.2139/ssrn.651341

Czarnitzki, D. and G. Licht (2006), "Additionality of public R\&D grants in a transition economy: The case of Eastern Germany", Economics of Transition, 14(1), 101-131. https://doi.org/10.1111/j.14680351.2006.00236.x

Czarnitzki, D., \& Lopes Bento, C. (2012). Evaluation of public R\&D policies: A cross-country comparison. World Review of Science, Technology and Sustainable Development, 9(2-4), 254-282. https://doi.org/10.1504/WRSTSD.2012.047690 
Czarnitzki, D., \& Lopes-Bento, C. (2014). Innovation subsidies: Does the funding source matter for innovation intensity and performance? Empirical evidence from Germany. Industry and Innovation, 21(5), 380-409. https://doi.org/10.1080/13662716.2014.973246

Crosby, M. (2000). „Patents, Innovation and Growth“. The Economic Record. Vol. 16. No. 234. 255-262. https://doi.org/10.1111/j.1475-4932.2000.tb00021.x

Dosi, G., Llerena, P., Sylos Labini, M. (2005). „Science-Technology-Industry Links and the European Paradox": Some Notes on the Dynamics of Scientific and Technological Research in Europe". Strasbourg: Pôle européen de gestion et d'économie (PEGE).

Dosi, G., Llerena, P., Sylos Labini, M. (2006) „The relationships between science, technologies and their industrial exploitation: An illustration through the myths and realities of the so-called 'European Paradox' “, Research Policy 35 1450-1464. https://doi.org/10.1016/j.respol.2006.09.012

Drucker, P. (1998). The Discipline of Innovation. Harvard Business Review On Point Edition (Product no. 3480), pp. 3-12. https://doi.org/10.1002/ltl.40619980906

Drzavni Zavod za Intelektualno vlasniztvo. (2010). Godiznje izvjezce 2009. Zagreb: Drzavni zavod za intelektualno vlasnistvo Republike Hrvatske.

EU council. (2011). Press releases RAPID. Preuzeto 08. 22012 iz Europa.eu: http://europa.eu/rapid/pressReleasesAction.do?reference=MEMO/11/59\&format=HTML\&aged=0\&lan guage $=E N \&$ guilanguage $=e n$

EU council. (2010). Press releases RAPID. Preuzeto 09. 022012 iz Europa.eu: http://europa.eu/rapid/pressReleasesAction.do?reference=IP/10/1288

Fleming, L., Singh, J. (2008). Lone Inventors as Sources of Breakthroughs: Myth or Reality? https://flora.insead.edu/fichiersti wp/inseadwp2008/2008-69.pdf (accessed 1. 3. 2017).

Frame, J. (1991). Modelling national technological capacity with patent indicators. Scientometrics, Volume 22, pp 327-339. https://doi.org/10.1007/BF02019766

Gambardella, A., Giuri, P., Mariani, M. (2005). The Value of European Patents Evidence From a Survey of European Inventors. http://ec.europa.eu/invest-inresearch/pdf/download en/patval mainreportandannexes.pdf (accessed 1. 3. 2017).

Garcia, R., Calantone, R. (2002). "A critical look at technological innovation typology and innovativeness terminology: a literature review", The Journal of Product Innovation Management, Vol. 19(2), 110132, DOI: 10.1111/1540-5885.1920110.

Garcia, A., Mohnen, P. (2010). Impact of government support on R\&D and innovation. UNU-MERIT

Global Competitive Index 2016-2017, $\quad$ http://www3.weforum.org/docs/GCR20162017/05FullReport/TheGlobalCompetitivenessReport2016-2017 FINAL.pdf

González, X., J. Jaumandreu and C. Pazó (2005), "Barriers to Innovation and Subsidy Effectiveness", Rand Journal of Economics, 36(4), 930-950.

Janssen, O., Van De Vliert, E. West, M. (2004). „The bright and dark sides of individual and group innovation: a Special Issue introduction". Journal of Organizational Behavior. Vol. 25, 129-145, DOI: 10.1002/job.242. 
Jones, B. F. (2009) "The Burden of Knowledge and the "Death of the Renaissance Man": Is Innovation Getting Harder?”. Review of Economic Studies 76, 283-317. https://doi.org/10.1111/j.1467937X.2008.00531.x

Kroslin, T. (2005). „Inovacijski potencial in uspešnost srednje velikih slovenskih podjetij iz predelovalnih dejavnosti“. Conference PODIM: Shaping the Environment for Innovation Transfer (str. 95). Maribor: Inštitut za podjetništvo in management malih podjetij Ekonomsko-poslovna fakulteta, Univerza v Mariboru.

Levitt, T. (1963). Creativity Is Not Enough. Harvard Business Review On Point Edition (Product no. 1628), pp. 15-28.

Meyer, M. (2004). Individual inventors, entrepreneurial activity and public support measures. Engineering Management Conference, 2004. Proceedings, Volume: 1, DOI:10.1109/IEMC.2004.1407108.

Nacionalno vijece za konkurentnost. (2009). Godišnje izvješće o konkurentnosti Hrvatske 2008. Zagreb: Nacionalno vijeće za konkurentnost.

Orly, L. (2013). Filing for a Patent Versus Keeping Your Invention a Trade Secret. https://hbr.org/2013/11/filing-for-a-patent-versus-keeping-your-invention-a-trade-secret (accessed 1.3. 2017).

Pozzi, A. (2010). Studija o inovacijskom potencijalu regija FIDIBE partnera ; Studija inovacijskog potencijala Hrvatske; . Athens: Centar za istraživanje i tehnologiju Hellas (Centre for Research and Technology Hellas) (CERTH).

Sanja Zelinski-Matunec, M. L.-P.-B.-S.-R. (2002). „Od ideje do profita vodic za inovatore - poduzetnike“. Zagreb: Ministarstvo za obrt, malo i srednje poduzetnistvo i Hrvatski savez inovatora.

Thomas, A. (2003). "The Return to Independent Invention:Evidence of Unrealistic Optimism, Risk Seekingor Skewness Loving?" The Economic Journal, Vol. 113 (January). pp. 226-239. https://doi.org/10.1111/1468-0297.00089

Veer, T., Jell, F. (2012). "Contributing to markets for technology? A comparison of patent filing motives of individual inventors, small companies and universities." Technovation Vol. 32 (9-10), pp. 513-522. https://doi.org/10.1016/j.technovation.2012.03.002

Veza, I., Prester, J. (2007). Inovacije u Hrvatskoj - istraživanje 2006 Rezultati br. 1 Revizija 1.0, 26.02.07. Zagreb: Ekonomski fakultet, Zagreb.

Vlada Republike Hrvatske. (2006). Strateški okvir za razvoj 2006.-2013. Zagreb: Vlada Republike Hrvatske.

Weitzman, M. L. (1998). Recombinant Growth. Quarterly Journal of Economics, Volume 113 (Issue 2), pp. 331-360. https://doi.org/10.1162/003355398555595

WIPO. Patents or Trade Secrets? http://www.wipo.int/sme/en/ip business/trade secrets/patent trade.htm (accessed 1. 3. 2017). 